\title{
Discovery of datolite in a high-pressure marble from the Sanbagawa metamorphic belt: Indication of B-rich fluid activity
}

\author{
Kenta Yoshida ${ }^{*}$, Sota NIKI ${ }^{* *}$, Hikaru SAWADA ${ }^{* * * * *}$ and Ryosuke OyanAGI \\ *Research Institute for Marine Geodynamics, Japan Agency for Marine-earth Science and Technology (JAMSTEC), \\ Yokosuka 237-0061, Japan \\ ${ }^{* *}$ Geochemical Research Center, Graduate School of Science, The University of Tokyo, Tokyo 113-0033, Japan \\ ${ }^{* * *}$ Institute for Extra-cutting-edge Science and Technology Avant-garde Research, Japan Agency for \\ Marine-earth Science and Technology (JAMSTEC), Yokosuka 237-0061, Japan
}

\begin{abstract}
Datolite $\left[\mathrm{CaBSiO}_{4}(\mathrm{OH})\right]$ was discovered in an eclogite-facies calcite marble collected from the Eastern Iratsu body in the Sanbagawa metamorphic belt of central Shikoku. The marble was composed of calcite, diopside, and garnet that contained inclusions of omphacite. Enclosed in the marble is a pod composed mainly of quartz, with subordinate calcite, diopside, and garnet that has inclusions of datolite. The formation conditions of the datolite were estimated on the basis of mineral assemblage and the Raman elastic geobarometer to be approximately $400-650{ }^{\circ} \mathrm{C}$ and $0.8-1.3 \mathrm{GPa}$, which coincide with the conditions of the eclogite juxtaposition with the non-eclogite units in the Besshi district. Our study records the highest pressure-temperature conditions as the metamorphic datolite formation. Our findings provide evidence for the occurrence of B-rich fluid infiltration during the juxtaposition of eclogite unit with the non-eclogite unit in the Besshi district.
\end{abstract}

Keywords: Datolite, Sanbagawa metamorphic belt, Deep fluid, B-rich fluid, Borosilicate

\section{INTRODUCTION}

Datolite $\left[\mathrm{CaBSiO}_{4}(\mathrm{OH})\right]$ is a hydrous borosilicate that is commonly formed through hydrothermal, volcanic, or low-grade metamorphic processes (Grew, 1996; Kiss et al., 2012). Although the stability limit of datolite, with respect to pressure $(P)$ and temperature $(T)$, is wide as $<700{ }^{\circ} \mathrm{C}$ at atmospheric pressure or $<5 \mathrm{GPa}$ at $250{ }^{\circ} \mathrm{C}$ (Tarney et al., 1973; Goryainov et al., 2015), datolite is sensitive with the composition of coexisting fluids, such as $\mathrm{H}^{+}$activity $(\mathrm{pH})$ and $\mathrm{H}_{3} \mathrm{BO}_{3}$ activity. On the basis of the experimental data, Yang and Rosenberg (1995) calculated the stable minerals in the system of $\mathrm{CaO}-\mathrm{B}_{2} \mathrm{O}_{3}-$ $\mathrm{SiO}_{2}-\mathrm{H}_{2} \mathrm{O}$, indicating that datolite is stable at high $\mathrm{pH}$ at a given $a_{\mathrm{Ca}^{2+}}$, where low $a_{\mathrm{Ca}^{2+}} / a_{\mathrm{H}^{+}}^{2}$ or high $a_{\mathrm{SiO}_{2}}$ conditions favor danburite $\left(\mathrm{CaB}_{2} \mathrm{Si}_{2} \mathrm{O}_{8}\right)$ instead of datolite.

This study reports the occurrence of datolite in a quartz pod containing grossular, calcite, and diopside en-

doi:10.2465/jmps.200730

K. Yoshida, yoshida_ken@jamstec.go.jp Corresponding author closed in an eclogite-facies marble. Datolite was discovered as inclusions in andradite-enriched patches in grossular for which the formation conditions were well constrained based on mineral assemblage and Ramanbased geobarometry. We report the highest $P-T$ conditions for the formation of metamorphic datolite. We also discuss the significance of datolite as a possible measure of B-rich fluid activity during the exhumation of eclogite-facies rock in the metamorphic terrain.

\section{GEOLOGICAL BACKGROUND}

The Sanbagawa metamorphic belt is a Cretaceous subduction complex where four mineral zones have been identified based on the mineral assemblages of pelitic schists. The succession with increasing peak metamorphic $T$ is (1) chlorite zone, which is equivalent to the prehnite-pumpellyite facies $\left(300^{\circ} \mathrm{C}, 0.5 \mathrm{GPa}\right)$, (2) garnet zone, (3) albite-biotite zone, and (4) oligoclase-biotite zone, which is equivalent to the epidote-amphibolite facies $\left(610{ }^{\circ} \mathrm{C}, 1.0 \mathrm{GPa}\right)$ (Higashino, 1990; Enami, 1994; 


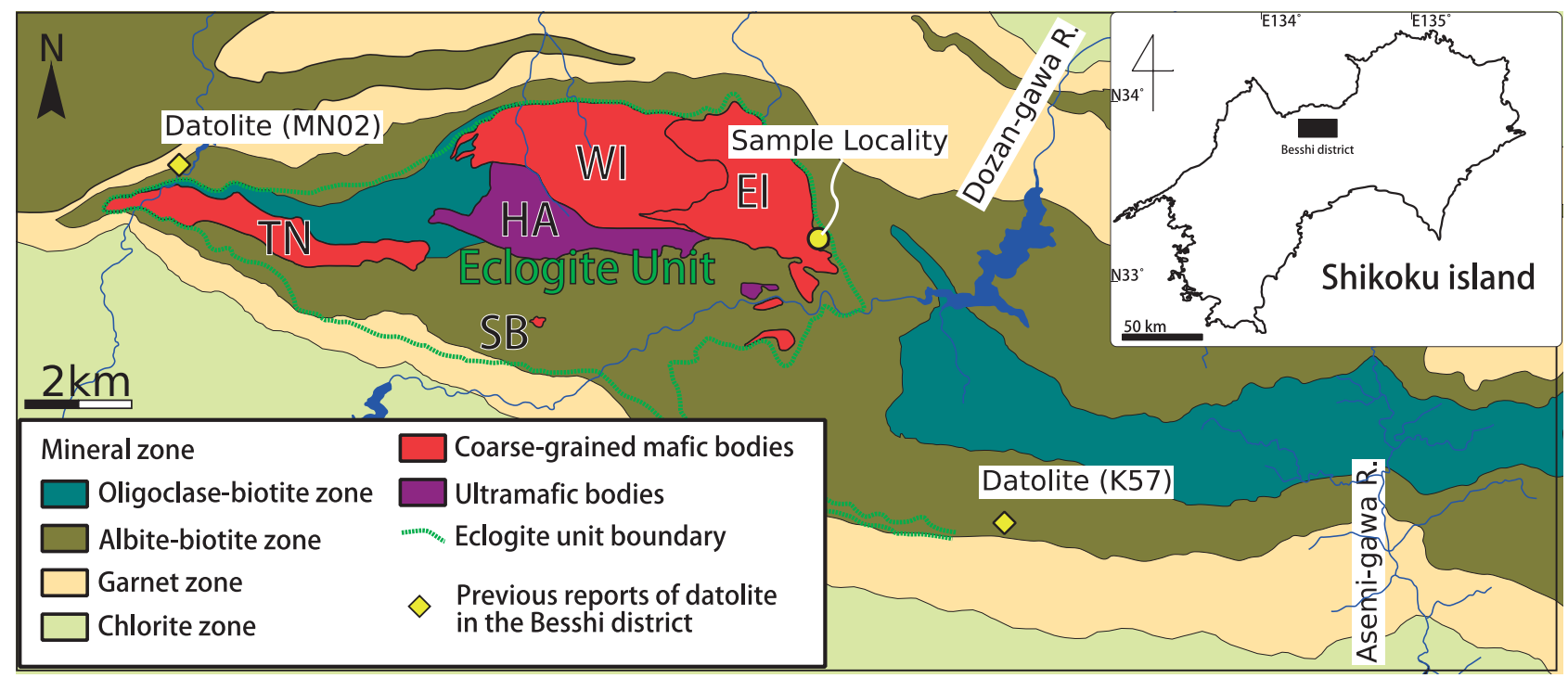

Figure 1. Simplified metamorphic zonation map of the Sanbagawa belt in the Besshi district, central Shikoku and the location of the studied sample, EI1901. The mineral zones of the non-eclogite unit were referenced from Higashino (1990), and the boundary between eclogite and non-eclogite units from Aoya et al. (2013). Previous reports on datolite in the relevant area are presented as yellow squares (K57, Kato et al., 1957; MN02, Minakawa and Nishio, 2002). Abbreviations for the coarse-grained mafic/ultramafic bodies are: Western Iratsu body (WI), Eastern Iratsu body (EI), Higashi-Akaishi peridotite body (HA), Tonaru body (TN), and Seba body (SB).

Aoya et al., 2013). In central Shikoku, eclogite-facies rocks, showing distinct high-pressure conditions, are widely distributed among the highest-grade parts of the albite- and oligoclase-biotite zones (Takasu, 1984; Aoya et al., 2013; Kouketsu et al., 2014a).

The Eastern Iratsu body is mainly composed of metamorphosed layered gabbro that has been subjected to the early stages of granulite-facies metamorphism and subsequent eclogite-facies metamorphism. This body is bordered by the albite-biotite zone to the east (Fig. 1; Takasu and Kohsaka, 1987). The datolite-bearing sample, EI1901, was obtained from the eastern margin area of the Eastern Iratsu body (Fig. 1). Previous reports of datolite and danburite in the Sanbagawa metamorphic belt were from a few localities in the garnet, albite-biotite, and oligoclase-biotite zones (Fig. 1; Kato et al., 1957; Minakawa and Nishio, 2002), where datolite occurs in veins formed during the retrograde stage.

\section{ANALYTICAL PROCEDURE}

The chemical compositions of the constituent minerals were analyzed at Japan Agency for Marine-Earth Science and Technology (JAMSTEC, Yokosuka, Japan) using an electron microprobe (EMP) analyzer with five wavelength dispersive X-ray detectors (JXA-8500F, JEOL). Synthetic and natural standards were employed in the quantitative analysis. X-rays were obtained using an accelerating voltage of $15 \mathrm{kV}$ and a beam current of $10 \mathrm{nA}$, except for datolite. For the analysis of datolite, a $5 \mathrm{nA}$ beam current was used to avoid damaging the sample, and synthetic boron nitride was used as the standard for boron analysis. The representative EMP analyses of garnet and datolite are presented in Table 1. Raman microscopy was performed using a Raman spectrophotometer (RAMANtouch, Nanophoton) at JAMSTEC using a 532 $\mathrm{nm}$ green laser. Laser power was obtained at $2-10 \mathrm{~mW}$ on the sample surface.

\section{PETROGRAPHY AND MINERAL CHEMISTRY}

EI1901 was collected from a marble outcrop (more than 3 $m$ in width) with many greenish mafic inclusions measuring several centimeters. Mafic rocks are recognized few meters away from the marble outcrop, although the contact between the two rock types is not visible owing to the surface soil. The studied sample is a weakly foliated marble containing several dark-colored spots of garnet (up to $5 \mathrm{~mm}$ ) and greenish spots of diopside $(<1 \mathrm{~mm}$ ) (Fig. 2a). The matrix of the sample mainly consists of calcite, diopside, and garnet. There are two modes of occurrence of calcite: faceted fine grains, and elongated coarse and anhedral grains. The latter defines the main foliation. The garnet in the matrix is colorless under thinsection observation and subhedral, containing abundant inclusions of omphacite, epidote, quartz, phengite, aragonite, and graphite with K-feldspar and albite possibly resulting from decomposition reactions. The diopside in 
Table 1. Representative chemical composition of garnet and datolite

\begin{tabular}{|c|c|c|c|}
\hline & \multicolumn{2}{|c|}{ Garnet } & \multirow{2}{*}{ Datolite } \\
\hline & Grt1 & Grt2 & \\
\hline $\mathrm{SiO}_{2}$ & 39.43 & 39.55 & 36.72 \\
\hline $\mathrm{TiO}_{2}$ & 0.07 & 0.07 & \\
\hline $\mathrm{Al}_{2} \mathrm{O}_{3}$ & 22.13 & 19.83 & \\
\hline $\mathrm{Cr}_{2} \mathrm{O}_{3}$ & 0.03 & 0.00 & 0.03 \\
\hline $\mathrm{FeO}^{*}$ & 0.63 & 3.67 & 0.00 \\
\hline $\mathrm{MnO}$ & 0.06 & 0.11 & 0.00 \\
\hline $\mathrm{MgO}$ & 0.07 & 0.02 & 0.00 \\
\hline $\mathrm{CaO}$ & 36.19 & 35.79 & 34.52 \\
\hline $\mathrm{Na}_{2} \mathrm{O}$ & 0.02 & 0.06 & \\
\hline $\mathrm{K}_{2} \mathrm{O}$ & 0.02 & 0.01 & \\
\hline $\mathrm{B}_{2} \mathrm{O}_{3}$ & & & 22.27 \\
\hline Total & 98.63 & 99.10 & 93.55 \\
\hline $\mathrm{O}=$ & 12 & 12 & 4.5 \\
\hline $\mathrm{Si}$ & 3.00 & 3.02 & 0.98 \\
\hline $\mathrm{Ti}$ & 0.00 & 0.00 & 0.00 \\
\hline $\mathrm{Al}$ & 1.99 & 1.78 & 0.00 \\
\hline $\mathrm{Cr}$ & 0.00 & 0.00 & 0.00 \\
\hline $\mathrm{Fe}^{3+}$ & 0.01 & 0.20 & 0.00 \\
\hline $\mathrm{Fe}^{2+}$ & 0.03 & 0.04 & 0.00 \\
\hline $\mathrm{Mn}$ & 0.00 & 0.01 & 0.00 \\
\hline $\mathrm{Mg}$ & 0.01 & 0.00 & 0.00 \\
\hline $\mathrm{Ca}$ & 2.95 & 2.93 & 0.99 \\
\hline $\mathrm{Na}$ & 0.00 & 0.01 & 0.00 \\
\hline K & 0.00 & 0.00 & 0.00 \\
\hline B & & & 1.03 \\
\hline Alm & 0.01 & 0.01 & \\
\hline Sps & 0.00 & 0.00 & \\
\hline Prp & 0.00 & 0.00 & \\
\hline Grs & 0.98 & 0.89 & \\
\hline Adr & 0.00 & 0.10 & \\
\hline$\Sigma\left(\mathrm{Al}+\mathrm{Fe}^{3+}+\mathrm{Ti}+\mathrm{Cr}\right)$ & 2.00 & 1.99 & \\
\hline
\end{tabular}

$\mathrm{Fe}^{3+} / \mathrm{Fe}^{2+}$ of garnet were calculated so that $\left(\mathrm{Ca}+\mathrm{Mg}+\mathrm{Mn}+\mathrm{Fe}^{2+}\right) /$ $\left(\mathrm{Al}+\mathrm{Fe}^{3+}+\mathrm{Cr}+\mathrm{Ti}\right)$ becomes 1.5 .

Some of Grt1 are not suitable for this calculation and are assumed all $\mathrm{Fe}$ are $\mathrm{Fe}^{2+}$.

the matrix is round in shape and almost devoid of mineral inclusions. A quartz pod is elongated parallel to the main foliation and contains quartz, garnet, calcite, and diopside with trace amounts of pyrite and titanite (Fig. 2a). The garnet grains in the quartz pod are subhedral and up to 3 $\mathrm{mm}$ across. It is almost pure grossular (Grs) with minor amounts of andradite (Adr) and almandine (Alm) components as described below. The scanning electron microscope (SEM) showed that the garnet in the quartz pod featured isolated and fragmented $\mathrm{Fe}$-poor cores with irregular outlines (Grt1) in a patchy matrix richer in $\mathrm{Fe}$ (Grt2) (Figs. 2b and 2c). These textures were caused by differences in the ferric iron content: Grt1 and Grt2 comprise $\mathrm{GrS}_{98-99} \mathrm{Adr}_{<1} \mathrm{Alm}_{1-2}$ and $\mathrm{Grs}_{88-92} \mathrm{Adr}_{1-11} \mathrm{Alm}_{1-6}$, respectively (Fig. 2e and Table 1). There is no systematic change of the compositional variation of Grt2. Grt1 contains inclusions of aragonite and minor amounts of $\mathrm{K}$ feldspar, while Grt2 contains calcite and quartz.

Datolite is exclusively found as subhedral, unzoned inclusions in Grt2 (Fig. 2d). The datolite grain exhibits a weakly faceted shape that is devoid of chemical zonation (Fig. 2d). The EMP analysis showed compositions that were identical to the ideal formulae of datolite, and the Raman spectra were consistent with those in the reference study (Table 1 and Fig. 3a; Lafuente et al., 2015). Datolite was neither found in garnet nor in diopside in the calcite marble hosting the quartz pod.

\section{FORMATION $P$ - $T$ CONDITIONS OF DATOLITE}

The occurrence of datolite in EI1901 strongly suggests that the datolite was formed simultaneously with Grt2. The formation $P-T$ conditions of Grt2 were estimated using a combination of quartz-Raman barometry and thermodynamic calculations. Quartz-Raman barometry is a pressure-estimation method that employs the frequency shift of quartz grains that are completely shielded in the garnet (Enami et al., 2007; Kouketsu et al., 2014b). The Raman shifts of quartz grains in Grt2 were measured, and $\Delta \omega_{1}$ values (difference in the distance between two peaks of $v_{464}$ and $v_{205}$ compared to a particular standard) were calculated according to the procedure reported by Kouketsu et al. (2014b). Figure $3 \mathrm{~b}$ shows the histogram of $\Delta \omega_{1}$ obtained from Grt2, yielding approximately $\Delta \omega_{1}=4.5$ for the most frequent value. Then, $\Delta \omega_{1}$ values were evaluated using the $P-T$ relationship reported by Kouketsu et al. (2014b) (Fig. 4b).

The temperature ranges were constrained using the mineral assemblage of grossular + quartz + calcite, because Grt2 contains quartz and calcite inclusions. The stability limits of grossular strongly depend on the composition of coexisting fluids involving $\mathrm{CO}_{2}$. For simplicity, we considered the stable mineral assemblage in the $\mathrm{CaO}-\mathrm{Al}_{2} \mathrm{O}_{3}-\mathrm{SiO}_{2}$ system along with the fluid of the $\mathrm{H}_{2} \mathrm{O}-$ $\mathrm{CO}_{2}$ binary mixture $\left(\mathrm{CASH}-\mathrm{CO}_{2}\right)$. The stability field of the assemblage grossular + quartz + calcite was bounded by the following $T$-sensitive reactions:

$$
\begin{aligned}
& \text { zoisite }+ \text { calcite }+ \text { quartz } \\
& \quad=\text { grossular }+\mathrm{H}_{2} \mathrm{O}+\mathrm{CO}_{2} \\
& \text { calcite }+ \text { quartz }=\text { wollastonite }+\mathrm{CO}_{2}
\end{aligned}
$$

As both reactions involve $\mathrm{CO}_{2}$ as a volatile component, the $X_{\mathrm{CO}_{2}}$ of the fluid strongly affects the position of 

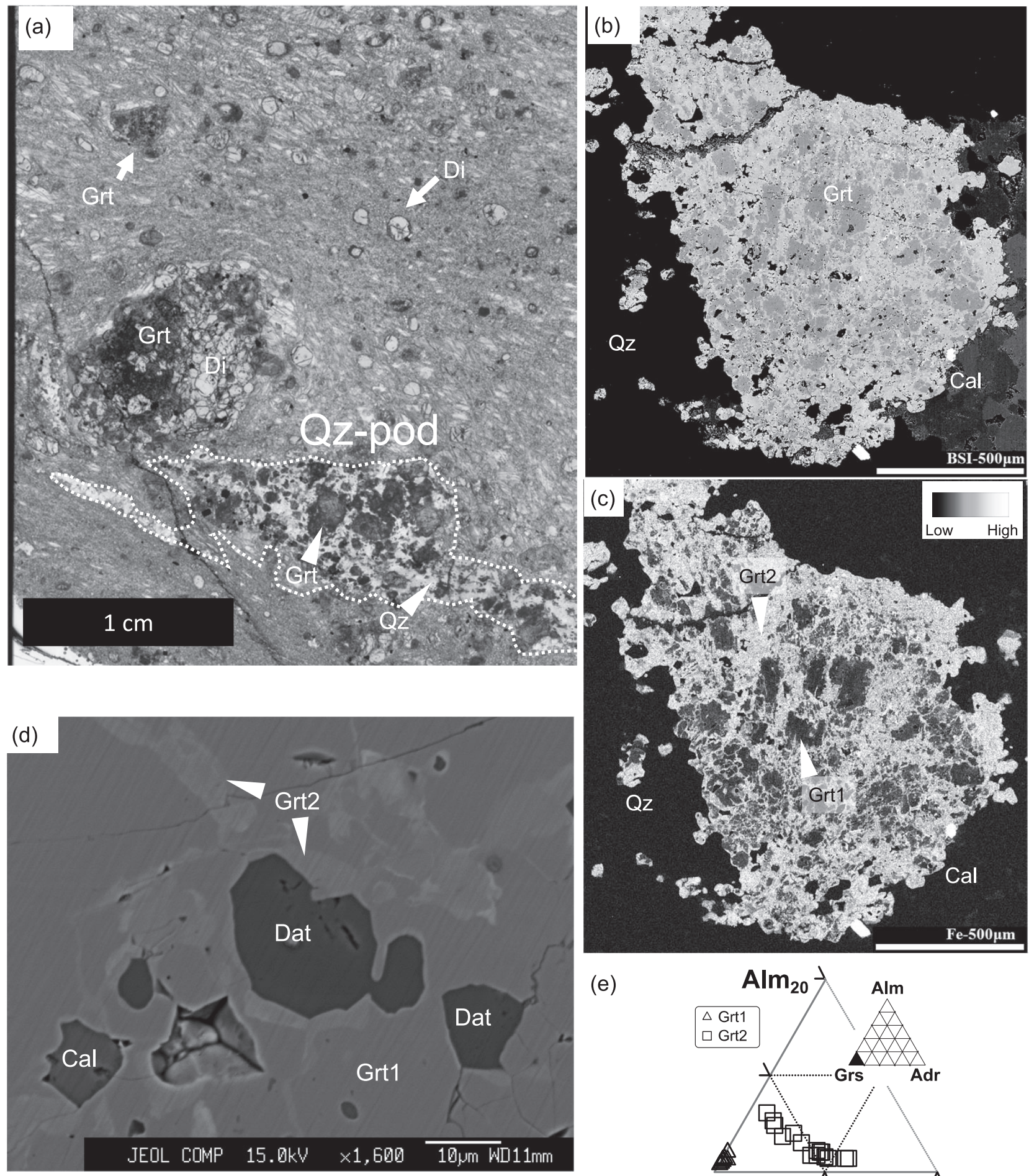

(e)

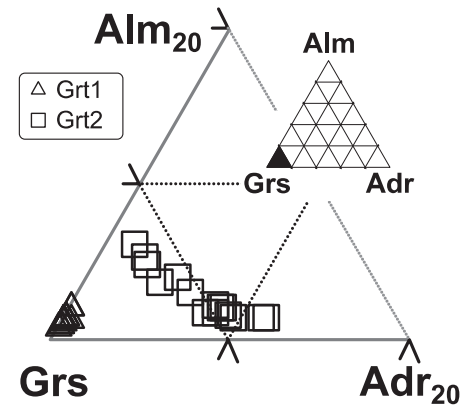

Figure 2. (a) A scan of the thinsection showing the microstructure of the studied sample (EI1901). (b) Back-scattered electron (BSE) image of the garnet in the quartz pod. (c) Fe X-ray image of the garnet in the quartz pod. The dark and bright part in the BSE image correspond to the Fe distribution. (d) BSE image of datolite found in the garnet in the quartz pod. The datolite grain shows faceted boundary and is surrounded by the Grt2. (e) Chemical composition of garnet in the quartz pod plotted in a ternary composition diagram. Abbreviations of the minerals are as follows: garnet (Grt), clinopyroxene $(\mathrm{Cpx})$, quartz $(\mathrm{Qz})$, calcite $(\mathrm{Cal})$, aragonite (Arg), datolite (Dat), almandine (Alm), grossular (Grs), and andradite (Adr). 


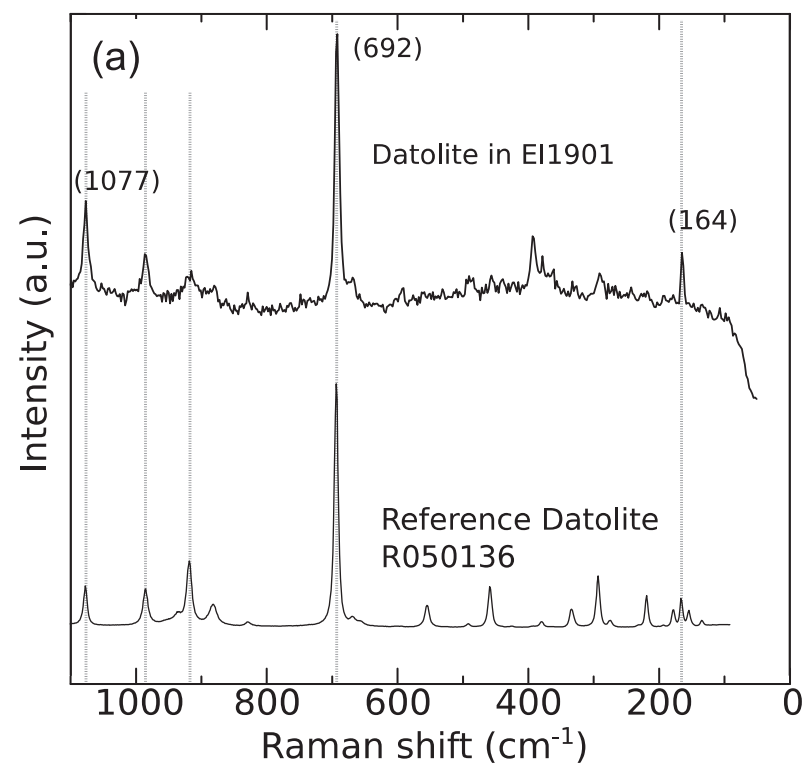

(b)

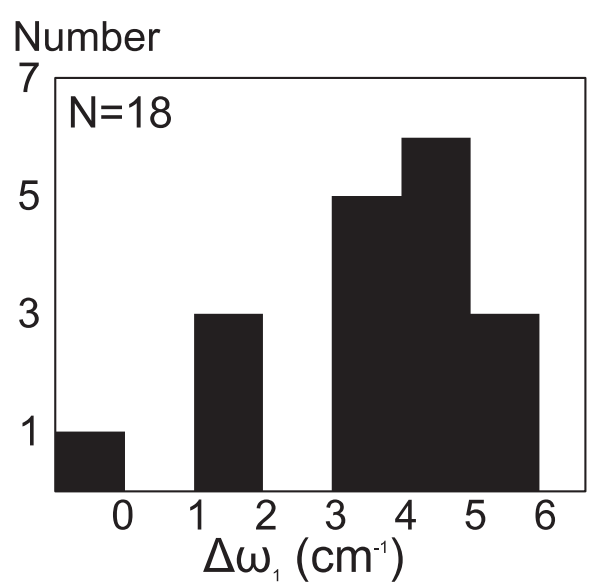

Figure 3. (a) Raman spectra of the datolite in the studied sample and reference data obtained from the online RRUFF database (https://rruff.info: Lafuente et al., 2015). The RRUFF sample number is also shown. (b) Histogram of $\Delta \omega_{1}$ values obtained from the quartz inclusions in the Grt2.

the reaction curves. The occurrence of datolite instead of danburite is an indication of low- $X_{\mathrm{CO}_{2}}$ conditions, where $X_{\mathrm{CO}_{2}}<0.02$ was inferred under $P-T$ conditions of $500{ }^{\circ} \mathrm{C}$ and $200 \mathrm{MPa}$ (Burt, 1978; Grew, 1996). Considering two reactions, a polybaric $T-X_{\mathrm{CO}_{2}}$ diagram for the range of $P=$ 0.8-1.2 GPa and a $P-T$ diagram based on the assumption of $X_{\mathrm{CO}_{2}}=0.01$ and 0.001 were calculated using Perple_X version 6.8.5 (Connolly, 2005) (Figs. 4a, and 4b).

The $T-X_{\mathrm{CO}_{2}}$ diagram adequately constrains the upper limit of $X_{\mathrm{CO}_{2}}$ to approximately 0.01 at $T<550{ }^{\circ} \mathrm{C}$ (Fig. $4 \mathrm{a})$. The two reaction curves and quartz-Raman barometry $\left(\Delta \omega_{1}=4.5\right)$ intersect at conditions of $400-650{ }^{\circ} \mathrm{C}$ and 0.8-1.3 GPa (Fig. 4b), which shows distinctly lower pressure than the estimated eclogite-facies conditions of the
Iratsu body (Takasu and Kohsaka, 1987; Ota et al., 2004).

\section{DISCUSSION AND IMPLICATIONS}

In the Besshi district, the exhumation $P-T$ history of the rocks in the eclogite unit were considered to be as follows: (1) decompression and cooling from the eclogite facies conditions $\left(\sim 650{ }^{\circ} \mathrm{C}, 2 \mathrm{GPa}\right)$ to the epidote-amphibolite facies $\left(\sim 550^{\circ} \mathrm{C}, 1 \mathrm{GPa}\right)$, (2) juxtaposition with the non-eclogite unit, which was also subjected to exhumation, and (3) the eclogite- and non-eclogite units were heated together to the peak temperature stage (Kouketsu et al., 2014a). As the carbonate inclusion species changed from aragonite to calcite during the transition from the growth of Grt1 to Grt2, the latter is considered to have formed during decompression stage (1) or (2) listed above. The estimated $P-T$ conditions are almost identical to that of the juxtaposition of the eclogite unit with the non-eclogite unit in the Besshi district (Fig. 4b).

The stability of the datolite in the $\mathrm{CaO}-\mathrm{B}_{2} \mathrm{O}_{3}-\mathrm{SiO}_{2}{ }^{-}$ $\mathrm{H}_{2} \mathrm{O}$ system is constrained by the following reactions:

$$
\begin{aligned}
& 2 \text { datolite }+2 \mathrm{H}^{+}=\text {danburite }+\mathrm{Ca}^{2+}+2 \mathrm{H}_{2} \mathrm{O} \\
& \text { wollastonite }+\mathrm{H}_{3} \mathrm{BO}_{3}=\text { datolite }+\mathrm{H}_{2} \mathrm{O} \\
& \text { quartz }+\mathrm{H}_{3} \mathrm{BO}_{3}+\mathrm{Ca}^{2+}=\text { datolite }+2 \mathrm{H}^{+} .
\end{aligned}
$$

These reactions qualitatively indicate that the stability of datolite favors either low $\mathrm{H}^{+}$activity or high $\mathrm{H}_{3} \mathrm{BO}_{3}$ activity. Figure $4 \mathrm{c}$ shows the stability relations of datolite, danburite, and wollastonite in the $\mathrm{CaO}-\mathrm{B}_{2} \mathrm{O}_{3}-\mathrm{SiO}_{2}-\mathrm{H}_{2} \mathrm{O}$ system under the conditions of $500{ }^{\circ} \mathrm{C}$ and $1 \mathrm{GPa}$. Calculations were conducted using the deep earth water (DEW) model (Sverjensky et al., 2014; Huang and Sverjensky, 2019) using DEW Excel spreadsheet version 11.0.2. The thermodynamic properties of datolite were sourced from the study by Yang and Rosenberg (1995), and those of wollastonite and quartz from the study by Berman (1988). As shown in Figure 4c, an increase in the activity of $\mathrm{H}_{3} \mathrm{BO}_{3}$, such as infiltration of B-rich fluid, would stabilize datolite at relatively high $a_{\mathrm{Ca}^{2+}} / a_{\mathrm{H}^{+}}^{2}$ conditions. Compared to the diagram illustrating relatively lower $T$ and $P\left(250{ }^{\circ} \mathrm{C}\right.$ and $\left.100 \mathrm{MPa}\right)$ (Yang and Rosenberg, 1995), the lower limit of $\log a_{\mathrm{H}_{3} \mathrm{BO}_{3}}$ was higher by approximately $1.5(-1.7)$. As a high $a_{\mathrm{Ca}^{2+}} / a_{\mathrm{H}^{+}}^{2}$ is also required to prevent the precipitation of danburite, if we include $\mathrm{CO}_{2}$ in the considered system and calcite precipitates from the solution, $a_{\mathrm{Ca}^{2+}} / a_{\mathrm{H}^{+}}^{2}$ would decrease; and datolite is decomposed to either quartz or danburite. The datolite in our sample is enclosed in Grt2. This is an indication of the simultaneous precipitation of datolite at the early stage of the precipitation of Grt2. The timing of datolite precip- 

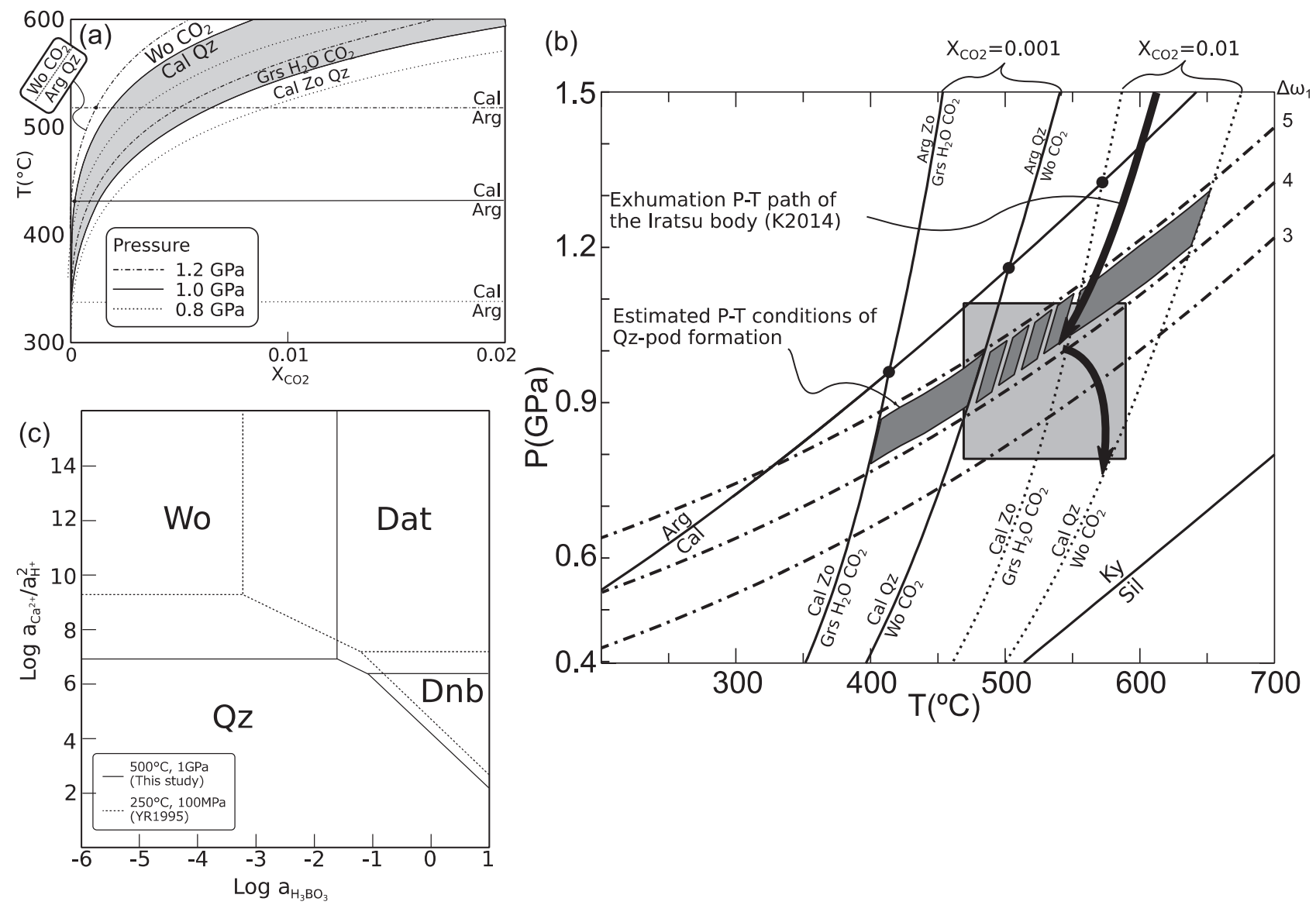

Figure 4. (a) Polybaric $T-X_{\mathrm{CO}_{2}}$ diagram showing univariant equilibria (1) and (2) in the text. Shaded area indicates the stability field of GrsQz-Cal/Arg assemblage at $1 \mathrm{GPa}$. (b) $P-T$ diagram showing the estimated formation conditions of the studied quartz pod. Univariant equilibria (1) and (2) were calculated for two $X_{\mathrm{CO}_{2}}$ conditions ( 0.01 and 0.001 drawn in solid and dotted lines, respectively). Dash-dotted lines show $\Delta \omega_{1}$ values projected in $P-T$ space. Grey box shows the peak $P-T$ conditions of the neighboring non-eclogite unit (albite-biotite zone) after Enami (1994). The exhumation $P-T$ path of the Iratsu body was also shown (K2014: Kouketsu et al., 2014a). Equilibria were calculated using Perple_X ver. 6.8.5 (Connolly, 2005). (c) Activity-activity stable relations of minerals in the $\mathrm{CaO}_{-} \mathrm{SiO}_{2}-\mathrm{B}_{2} \mathrm{O}_{3}-\mathrm{H}_{2} \mathrm{O}$ system were calculated using the DEW Excel spreadsheet version 11.0.2 (Sverjensky et al., 2014; Huang and Sverjensky, 2019). Diagram for 250 ${ }^{\circ} \mathrm{C}$ and $100 \mathrm{MPa}$ (YR1995: Yang and Rosenberg, 1995) is also shown by dotted lines. Mineral abbreviations are as follows: aragonite (Arg), calcite (Cal), chlorite (Chl), danburite (Dnb), datolite (Dat), garnet (Grt), albite (Ab), biotite (Bt), oligoclase (Olg), kyanite (Ky), andalusite (And), sillimanite (Sil), zoisite (Zo), grossular (Grs), wollastonite (Wo), and anorthite (An).

itation may have been limited as the datolite inclusion is rare. Subsequently, during the same fluid infiltration event, calcite may have precipitated from the fluid, and datolite became unstable, resulting in the absence of datolite in the entire quartz pod.

Based on the chemical composition of fluid inclusions in syn-metamorphic quartz veins, Yoshida et al. (2015) showed the B- and Li-rich aqueous fluid activity (up to $\sim 300 \mu \mathrm{g} / \mathrm{g}$ each) during the peak to early exhumation stage of the Sanbagawa metamorphic belt. The squeezing of $\mathrm{B}$ and $\mathrm{Li}$ from metamorphosed mafic rocks is attributable to the partitioning behavior of these elements between minerals and aqueous fluids under the conditions of $400-1000{ }^{\circ} \mathrm{C}$ and 1.5-4 GPa (Brenan et al., 1998; Kessel et al., 2005; Marschall et al., 2006, 2007).
Yoshida et al. (2011) calculated the partitioning coefficient of $\mathrm{B}$ between aqueous fluid and a metapelite collected from the oligoclase-biotite zone of the Besshi district under the prograde $P-T$ path of the relevant area, indicating a considerable release of $\mathrm{B}$ from the subducting metapelites. Despite the origin of the fluid that affected Grt2formation being unclear, B-enriched aqueous fluids can be derived externally from the surrounding rocks of the Eastern Iratsu body at the timing of the juxtaposition.

Sunada and Sakakibara $(2004,2006)$ reported tourmaline-rich layer from the adjacent area of the eclogite unit of the Besshi district. Based on the mode of occurrence and coexisting minerals, they indicated that B-rich aqueous fluid activity took place during the peak metamorphic stage of the non-eclogite unit (i.e., epidote-am- 
phibolite facies conditions). In many subduction-related rocks, a common borosilicate is tourmaline as it is stable over wide $P-T$ range (Schreyer and Werding, 1997; Dutrow and Henry, 2011), and thus, tourmaline is used to decipher B-rich fluid activity (e.g., Kawakami et al., 2019). However, the experimental study of amphibolite and B-bearing fluids indicates that tourmaline becomes unstable under alkaline conditions $(\mathrm{pH}>\sim 6.5-7.0)$ regardless of the boron concentration in mafic system (Morgan and London, 1989). In contrast, datolite can be stable under alkaline (low $a_{\mathrm{H}^{+}}$) and high $a_{\mathrm{H}_{3} \mathrm{BO}_{3}}$ conditions in calcic system. Our findings regarding datolite formed under epidote-amphibolite facies conditions provide new form of the evidence of B-bearing fluid activity in calcsilicate rocks.

\section{ACKNOWLEDGMENTS}

We are grateful T. Hirajima and K. Asakura for the discussions regarding the studied sample and relevant area. We thank R. Halama for his constructive comments on the early version of the manuscript. This manuscript benefited from constructive reviews by E.S. Grew and an anonymous reviewer, and editorial handling by $\mathrm{T}$. Kawakami. This study was partly supported by JSPS KAKENHI Grant Nos. JP19K14825 and JP19H01999 for KY, Joint Usage and Research Program of the Earthquake Research Institute, the University of Tokyo (ERI JURP 2018-B-01), and NOZOMI Farm. We would like to thank Editage for English language editing.

\section{REFERENCES}

Aoya, M., Noda, A., Mizuno, K., Mizukami, T., et al. (2013) Geology of Niihama district. Quadrangle Series, 1:50,000. pp.181, Geological Survey of Japan, AIST. (in Japanese with English abstract).

Berman, R.G. (1988) Internally-consistent thermodynamic data for minerals in the system $\mathrm{Na}_{2} \mathrm{O}-\mathrm{K}_{2} \mathrm{O}-\mathrm{CaO}-\mathrm{MgO}-\mathrm{FeO}-\mathrm{Fe}_{2} \mathrm{O}_{3}-$ $\mathrm{Al}_{2} \mathrm{O}_{3}-\mathrm{SiO}_{2}-\mathrm{TiO}_{2}-\mathrm{H}_{2} \mathrm{O}-\mathrm{CO}_{2}$. Journal of Petrology, 29, 445522.

Brenan, J.M., Ryerson, F.J. and Shaw, H.F. (1998) The role of aqueous fluids in the slab-to-mantle transfer of boron, beryllium, and lithium during subduction: experiments and models. Geochimica et Cosmochimica Acta, 62, 3337-3347.

Burt, D.M. (1978) Tin silicate-borate-oxide equilibria in skarns and greisens-The system $\mathrm{CaO}-\mathrm{SnO}_{2}-\mathrm{SiO}_{2}-\mathrm{H}_{2} \mathrm{O}-\mathrm{B}_{2} \mathrm{O}_{3}-\mathrm{CO}_{2}-$ $\mathrm{F}_{2} \mathrm{O}_{-1}$. Economic Geology, 73, 269-282.

Connolly, J.A.D. (2005) Computation of phase equilibria by linear programming: A tool for geodynamic modeling and its application to subduction zone decarbonation. Earth Planetary Science Letters, 236, 524-541.

Dutrow, B.L. and Henry, D.J. (2011) Tourmaline: A Geologic DVD. Elements, 7, 301-306.

Enami, M. (1994) Sanbagawa metamorphism: implication for evo- lution of a subduction zone. Journal of Mineralogy, Petrology and Economic Geology, 89, 409-422.

Enami, M., Nishiyama, T. and Mouri, T. (2007) Laser Raman microspectrometry of metamorphic quartz: A simple method for comparison of metamorphic pressures. American Mineralogist, 92, 1303-1315.

Goryainov, S.V., Krylov, A.S., Vtyurin, A.N. and Pan, Y. (2015) Behavior of $\mathrm{CaBSiO}_{4}(\mathrm{OH})$ datolite at high temperatures and pressures of a water medium. Bulletin of Russian Academy Science and Physics, 79, 794-797.

Grew, E.S. (1996) Borosilicates (exclusive of tourmaline) and boron in rock-forming minerals in metamorphic environments. In Boron mineralogy, petrology and geochemistry (Grew, E.S. and Anovitz, L.M. Eds). pp. 862, Reviews in Mineralogy and Geochemistry, 33, Mineralogical Society of America, Washington, D.C., 387-502.

Higashino, T. (1990) The higher grade metamorphic zonation of the Sambagawa metamorphic belt in central Shikoku, Japan. Journal of Metamorphic Geology, 8, 413-423.

Huang, F. and Sverjensky, D.A. (2019) Extended Deep Earth Water Model for predicting major element mantle metasomatism. Geochimica et Cosmochimica Acta, 254, 192-230.

Kato, A., Kanehira, K. and Horikoshi, A. (1957) On datolites from Hoino, Nakagawa village, Shuso district, Ehime Prefecture and Shirataki Mine, Tosa district, Kochi Prefecture. The Journal of the Japanese Association of Mineralogists, Petrologists and Economic Geologists, 41, 198-200 (in Japanese).

Kawakami, T., Sakai, H. and Sato, K. (2019) Syn-metamorphic Bbearing fluid infiltrations deduced from tourmaline in the Main Central Thrust zone, Eastern Nepal Himayalas. Lithos, 348-349, 105175.

Kessel, R., Schmidt, M.W., Ulmer, P. and Pettke, T. (2005) Trace element signature of subduction-zone fluids, melts and supercritical liquids at $120-180 \mathrm{~km}$ depth. Nature, 437, 724-727.

Kiss, G., Molnár, F. and Zaccarini, F. (2012) Fluid inclusion studies in datolite of low grade metamorphic origin from a Jurassic pillow basalt series in northeastern Hungary. Central European Journal of Geosciences. 4, 261-274.

Kouketsu, Y., Enami, M., Mouri, T., Okamura, M. and Sakurai, T. (2014a) Composite metamorphic history recorded in garnet porphyroblasts of Sambagawa metasediments in the Besshi region, central Shikoku, Southwest Japan. Island Arc, 23, 263280.

Kouketsu, Y., Nishiyama, T., Ikeda, T. and Enami, M. (2014b) Evaluation of residual pressure in an inclusion-host system using negative frequency shift of quartz Raman spectra. American Mineralogist, 99, 433-442.

Lafuente, B., Downs, R.T., Yang, H. and Stone, N. (2015) The power of databases: the RRUFF project. In Highlights in Mineralogical Crystallography (Armbruster, T. and Danisi, R.M. Eds.). W. De Gruyter, Berlin, Germany, 1-30.

Marschall, H.R., Altherr, R., Ludwig, T., Kalt, A., et al. (2006) Partitioning and budget of $\mathrm{Li}, \mathrm{Be}$ and $\mathrm{B}$ in high-pressure metamorphic rocks. Geochimica et Cosmochimica Acta, 70, 4750-4769.

Marschall, H.R., Altherr, R and Rüpke, L. (2007) Squeezing out the slab-modelling the release of $\mathrm{Li}, \mathrm{Be}$ and $\mathrm{B}$ during progressive high-pressure metamorphism. Chemical Geology, 239, 323-335.

Minakawa, T. and Nishio, D. (2002) Danburite from basic schist of Sambagawa belt in Shikoku, Japan. Memoir of Faculty of Science, Ehime University, 8, 11-17. 
Morgan, G.B. and London, D. (1989) Experimental reactions of amphibolite with boron-bearing aqueous fluids at $200 \mathrm{MPa}$ : implications for tourmaline stability and partial melting in mafic rocks. Contributions to Mineralogy and Petrology, 102, 281-297.

Ota, T., Terabayashi, M. and Katayama, I. (2004) Thermobarometric structure and metamorphic evolution of the Iratsu eclogite body in the Sanbagawa belt, central Shikoku, Japan. Lithos, 73, 95-126.

Schreyer, W. and Werding, G. (1997) High-pressure behaviour of selected boron minerals and the question of boron distribution between fluids and rocks. Lithos, 41, 251-266.

Sunada, D. and Sakakibara, M. (2004) Tourmaline-rich layers of eclogite nappe in the Sanbagawa metamorphic belt, central Shikoku, Japan. Abstract of the Annual Meeting of the Geological Society of Japan, P-199 (in Japanese).

Sunada, D. and Sakakibara, M. (2006) Tourmaline-bearing amphibolite in Sanbagawa belt of the Kokuryogawa area, central Shikoku, Japan. Memoir of Faculty of Science, Ehime University, 12, 29-37.

Sverjensky, D.A., Harrison, B. and Azzolini, D. (2014) Water in the deep Earth: The dielectric constant and the solubilities of quartz and corundum to $60 \mathrm{~kb}$ and $1200{ }^{\circ} \mathrm{C}$. Geochimica et Cosmochimica Acta, 129, 125-145.

Takasu, A. (1984) Prograde and retrograde eclogites in the Samba- gawa metamorphic belt, Besshi district, Japan. Journal of Petrology, 25, 619-643.

Takasu, A. and Kohsaka, Y. (1987) Eclogites from the Iratsu epidote amphibolite mass in the Sambagawa metamorphic belt, Besshi district, Japan. Journal of Geological Society of Japan, 93, 517-520 (in Japanese).

Tarney, J., Nicol, A.W. and Marriner, G.F. (1973) The thermal transformation of datolite, $\mathrm{CaBSiO}_{4}(\mathrm{OH})$, to boron melilite. Mineralogical Magazine, 39, 158-175.

Yang, W. and Rosenberg, P.E. (1995) The free energy of formation of datolite. American Mineralogist, 80, 576-584.

Yoshida, K., Sengen, Y., Tsuchiya, S., Minagawa, K., et al. (2011) Fluid inclusions with high $\mathrm{Li} / \mathrm{B}$ ratio in a quartz vein from the Besshi area of the Sambagawa metamorphic belt: implications for deep geofluid evolution. Journal of Mineralogical and Petrological Sciences, 106, 164-168.

Yoshida, K, Hirajima, T., Ohsawa, S., Kobayashi, T., et al. (2015) Geochemical features and relative $\mathrm{B}-\mathrm{Li}-\mathrm{Cl}$ compositions of deep-origin fluids trapped in high-pressure metamorphic rocks. Lithos, 226, 50-64.

Manuscript received July 30, 2020

Manuscript accepted October 25, 2020

Published online December 8, 2020

Manuscript handled by Tetsuo Kawakami 